\title{
Analisa Karakteristik Dan Distribusi Hujan Pada Kawasan DAS Batang Hari Kabupaten Dharmasraya
}

\section{Characteristic Analysis and Ranfall Distributionc at DAS Batang Hari Kabupaten Dharmasraya}

\author{
Hartati \\ Jurusan Teknik Sipil Politeknik Negeri Padang Kampus Limau Manis Padang \\ Telp.0751-72590 Fax.0751-72576 Email: tatiana.trinita@gmail.com
}

\begin{abstract}
Batang Hari is the 2nd biggest DAS in Indonesia. About $76 \%$ of Batang Hari DAS is located in Jambi Province, the entire 24\% is in West Sumatera Province. Batang Hari dam which was built on 1997 is one of infrastrcture at Public Work ministery under management at Balai Wilayah Sungai Sumatera V (BWSS V) his high potential of water stock. Optimum discharge of Batang Hari Dam is about $86 \mathrm{~m}^{3} / \mathrm{sec}$. In the recently years DAS Batang Hari has been disturbed by some changes like catchment area utilized fot other purpose, change on global climate done to greenhouse effectwhich causingintensity of rain as well as flood. This climate change then will affected standard for engineering design for making a water control buiding which may injuireaccurate waterfall intensity data. Study of rainfall intensity obtained from 3 (three) nearby stations will show the characteristic dam trend of distribution with reperted period. Cousistency of data using Mass Curve method and local rain analysis to be done by Arithmatic \& Thiessen Polygon method. To analysis trend of rainfall distribution. We use : Normal, Log Normal, Log Person type III and Gumbel methods. For complaince test of distribution, we use Chi-Kuadrat and Smirnov-Kolmogorov methods. Refer to result of distribution using ChiKuadrat and Smirnov-Kolmogorov methods for Arithmatic methods it is adviced to use Gumbel method to evaluate distribution trend; because critical deviation is smell comparing to available in table, with rainfall with repeating period 2,5,10,25,50 and 100 years are $124,08 \mathrm{~mm}, 1168,56 \mathrm{~mm}, 198,01 \mathrm{~mm}, 235,22 \mathrm{~mm}, 262,83 \mathrm{~mm}$, 290,23 mm and Thiessen Polygon 106,93 mm, 138,22 mm, 158,94 mm, 185,11 mm, 204,53 mm, 223,81 mm
\end{abstract}

Keyword : river basin, characteristic, rainfall, test of distribution

\section{PENDAHULUAN}

Hujan merupakan salah satu jenis presipitasi yang jatuh vertikal di atas permukaan bumi dan diukur oleh penakar hujan. Hujan jatuh dalam bentuk tetesan yang dikondensasikan oleh uap air di atmosfer (Seyhan,1990). Wilayah tangkapan air hujan yang akan mengalir ke sungai yang bersangkutan disebut Daerah Aliran Sungai (DAS) (Girsang,2008).

DAS Batang Hari merupakan DAS terbesar kedua di Indonesia. Sekitar 76\% DAS Batang Hari berada di Propinsi Jambi dan sisanya berada di Sumatera Barat. Bendung Batang Hari yang pelaksanaan pembangunannya tahun 1997 didanai oleh Japan Bank for International cooperation (JBIC), berada di kabupaten Dharmasraya dan merupakan salah satu Infrastruktur
Sumber Daya Air yang berada di bawah pengelolaan Balai Wilayah Sungai Sumatera V (BWSS V), memiliki potensi kelebihan air yang tinggi. Debit Andalan Bendung Batang Hari adalah $86 \mathrm{~m} 3 / \mathrm{dt}$, dan yang didesain untuk dimanfaatkan irigasi hanya $25 \mathrm{~m} 3 / \mathrm{det}$ untuk mengairi areal sawah seluas 18.986 ha yang meliputi 48 Jorong (36 desa) di Sumatera Barat dan 5 desa di Propinsi Jambi. Beberapa tahun terakhir di DAS Batanghari telah terjadi banyak perubahan tutupan lahan akibat alih fungsi lahan dan juga perubahan kondisi iklim bumi akibat efek rumah kaca yang berdampak pada penyimpangan iklim yang nyata, sehingga meningkatnya intensitas curah hujan dan banjir.

Perubahan kondisi iklim ini memiliki potensi untuk mempengaruhi standar rancangan keteknikan di masa yang akan datang. Dalam 
perencanaan bangunan pengendali banjir (saluran drainase, tanggul, dll) data masukan curah hujan sangat diperlukan. Para ahli teknik sipil (air), para ahli geomorfologi, para ahli konservasi tanah dan air lebih tertarik untuk melakukan analisa frekuensi kejadian klimatis yang ekstrim pada intensitas hujan dan lama waktu yang berbeda dengan menggunakan kurva IDF (Susilowati, 2010).

Tujuan dari penelitian ini adalah untuk menganalisa karakteristik dan distribusi hujan dari tiga stasiun penakar curah hujan yang ada dikawasan DAS Bendung Batang Hari. Dan dari hasil penelitian yang diperoleh ini, selanjutnya dapat dimanfaatkan untuk menghitung debit banjir rencana yang diperlukan dalam perencanaan bangunan pengendali banjir.

\section{METODOLOGI}

Metode yang dilakukan dalam penelitian ini adalah dengan cara mengumpulkan data yang diperlukan, menganalisa data, dan menginterpretasi hasil analisa data untuk mendapatkan informasi guna pengambilan keputusan kesimpulan. Lokasi penelitian adalah di Catchment Area Bendung Batang Hari (lihat gambar 1), sedangkan data curah hujan dari tiga stasiun curah hujan yang terpilih yaitu stasiun curah hujan Durian Simpai Lago, stasiun curah hujan Bendung Batang Hari dan stasiun curah hujan Muaro Labuh (lihat tabel 1) Data curah hujan dari tahun 2001 sampai dengan tahun 2015 dan data ini diperoleh dari Balai Wilayah Sungai Sumatera V.

Metode penelitian berikutnya adalah dari data curah hujan yang diperoleh dari ketiga stasiun curah hujan tersebut dianalisa dulu data curah hujan maksimum tahunan, kemudian uji kekonsisten data dengan kurva massa ganda. Setelah diperoleh data yang konsisten, lakukanlah analisa curah hujan rata-rata dengan metode Aljabar dan Poligon Thiessen. Hasil analisa curah hujan rerata dengan kedua metoda tersebut,dilakukan analisa penentuan jenis sebaran distribusi hujan dengan empat metode yaitu Metode Normal, Metode Gumbel , Metode Log Normal dan Metode Log Person III, dan kemudian dilanjutkan dengan pengujian pola distribusi hujan dengan Metoda SmirnovKolmogorov dan Metoda Chi-Kuadrat. Untuk pengelolaan peta Das dan pembuatan peta wilayah dari data DEM dan untuk pengelolaan data hujan menggunakan Microsoft Excel.

Tabel 1. Nama Stasiun Curah Hujan dan lokasi

\begin{tabular}{lcc}
\hline $\begin{array}{l}\text { Nama } \\
\text { Stasiun } \\
\text { Curah Hujan }\end{array}$ & $\begin{array}{c}\text { Lintang } \\
\text { Selatan }\end{array}$ & Bujur Timur \\
\hline $\begin{array}{l}\text { Sta. Durian } \\
\text { Simpai }\end{array}$ & $01^{\circ} 00^{\prime} 35,1^{\prime \prime}$ & $101^{\circ} 22^{\prime} 56,9^{\prime \prime}$ \\
Silago (A) & & \\
Sta Bendung & $01^{\circ} 00^{\prime} 12,7^{\prime \prime}$ & $100^{\circ} 26^{\prime} 15,2^{\prime \prime}$ \\
Batang Hari & & \\
(B) M Muara & $01^{\circ} 28^{\prime} 48,0^{\prime \prime}$ & $101^{\circ} 02^{\prime} 24,0^{\prime \prime}$ \\
Sta. M. M & \\
Labuh (C) & & \\
\hline
\end{tabular}




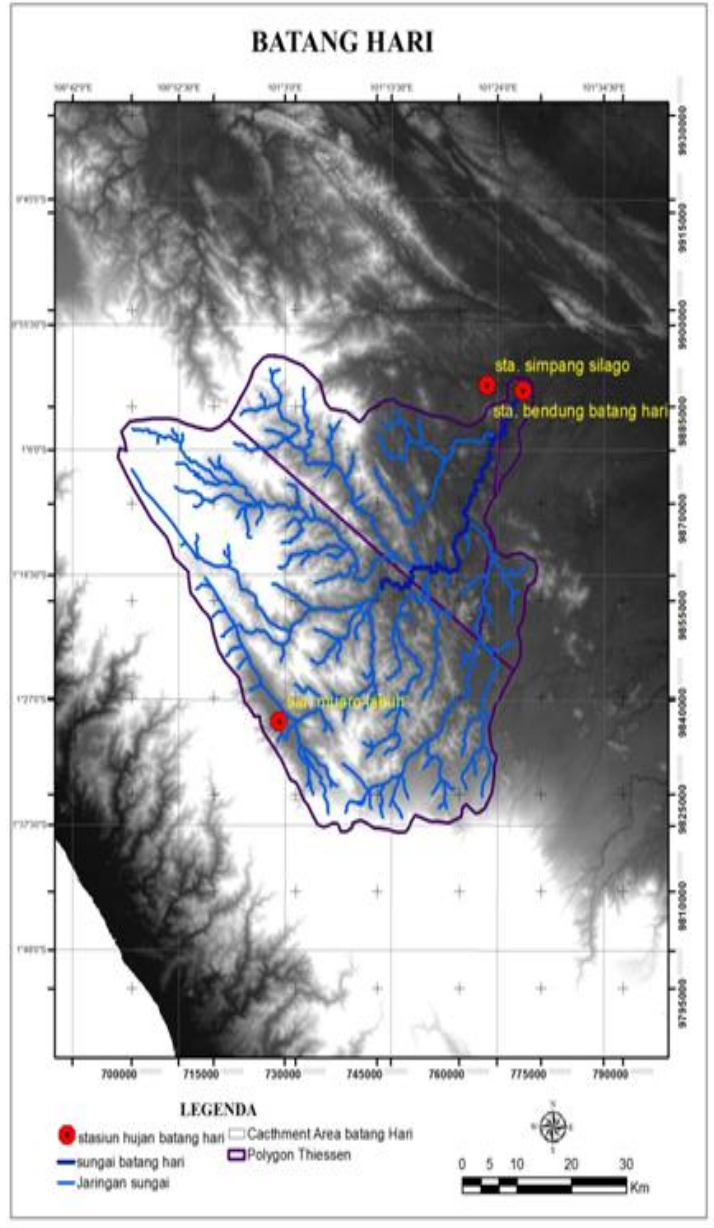

Gambar 1. Peta Cacthment Area DAS Batang Hari dan Data DEM

\section{HASIL DAN PEMBAHASAN}

Dalam menganalisa data curah hujan yang diperoleh dari ke tiga stasiun penakar curah hujan terlebih dahulu dilakukan analisa data curah hujan maksimum tahunan yang dimulai dari tahun 2001 - tahun 2015. Kemudian data yang diperoleh ini perlu diuji kevalidan data karena kemungkinan data ada yang tidak valid akibat alat rusak, alat pernah berpindah tempat, lokasi alat terganggu dan lain-lain. Dalam penelitian ini kevalidan data dilakukan dengan Kurva Massa Ganda.

Metode Aritmatika

Metode yang paling sederhana untuk menghitung hujan rerata pada suatu daerah adalah dengan metoda aritmatika. Dengan metoda ini, dilakukan analisa rerata hujan dari data yang sudah diuji kevalidannya Pengukuran yang dilakukan di beberapa stasiun dalam waktu yang bersamaan dijumlahkan dan kemudian dibagi dengan jumlah stasiun. Stasiun hujan yang digunakan dalam hitungan biasanya adalah yang berada didalam DAS, tetapi stasiun diluar DAS yang masih berdekatan juga bisa diperhitungkan.

Hujan rerata pada seluruh DAS diberikan oleh bentuk berikut ini:

$$
\overline{\mathrm{P}}=\frac{\left(\mathrm{P}_{1}+\mathrm{P}_{2}+\ldots+\mathrm{P}_{\mathrm{n}}\right)}{\mathrm{n}}
$$

Dimana:

$$
\begin{aligned}
& \overline{\mathrm{P}} \quad \text { : Hujan rerata kawasan } \\
& \mathrm{P}_{1}, \mathrm{P}_{2}, \mathrm{P}_{\mathrm{n}} \text { : Hujan pada stasiun } 1,2, \ldots, \mathrm{n} \\
& \mathrm{n} \quad \text { : Jumlah Stasiun }
\end{aligned}
$$

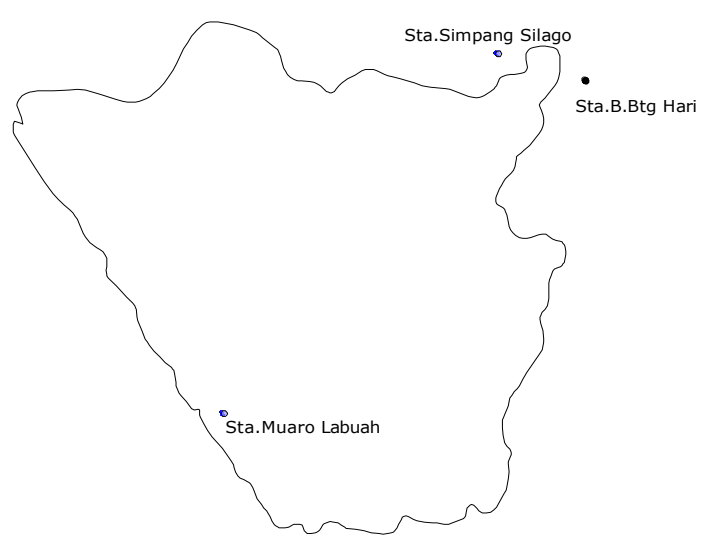

Gambar 2. Peta Stasiun Hujan di DAS Batang Hari

Metode Poligon Thiessen

Metode ini memperhitungkan bobot dari masing-masing stasiun yang mewakili luasan di sekitarnya. Pada suatu luasan di dalam DAS di anggap bahwa hujan adalah sama dengan yang terjadi pada stasiun yang terdekat, sehingga hujan yang tercatat pada suatu stasiun mewakili luasan tersebut. Metode ini digunakan apabila penyebaran stasiun hujan di daerah yang ditinjau tidak merata. Hitungan curah hujan rerata dilakukan dengan memperhitungkan daerah pengaruh dari tiap stasiun.

Secara matematis hujan rerata dapat ditulis sebagai berikut :

$$
\overline{\mathrm{P}}=\frac{\left(\mathrm{A}_{1} \mathrm{P}_{1}+\mathrm{A}_{2} \mathrm{P}_{2}+\ldots+\mathrm{A}_{\mathrm{n}} \mathrm{P}_{\mathrm{n}}\right)}{\left(\mathrm{A}_{1}+\mathrm{A}_{2}+\ldots \mathrm{A}_{n}\right)}
$$


Dimana:

$\overline{\mathrm{P}} \quad$ : Hujan rerata kawasan

$\mathrm{P}_{1}, \mathrm{P}_{2}, \mathrm{P}_{\mathrm{n}}$ : Hujan pada stasiun $1,2, \ldots, \mathrm{n}$

$\mathrm{A}_{1}, \mathrm{~A}_{2}, \mathrm{~A}_{\mathrm{n}}$ : Luas daerah yang mewakili stasiun $1,2, \ldots, \mathrm{n}$

Sebelum menghitung hujan rerata, lokasi pos penakar hujan di plot pada peta dan antar pos penakar dibuat garis lurus penghubung. Tarik garis tegak lurus di tengah-tengah tiap garis penghubung sedemikian rupa sehingga membentuk poligon Thiessen. Luasan wilayah tiap poligon diukur terlebih dahulu dengan metode grid seperti terlihat pada gambar 1dan diperoleh data luasan wilayah masing-masing curah hujan dari ketiga stasiun seperti pada tabel 2 .

Tabel 2. Data luasan wilayah

\begin{tabular}{|c|c|}
\hline Stasiun Curah Hujan & Luas $\left(\mathrm{km}^{2}\right)$ \\
\hline
\end{tabular}

(A)

Bendung Batang Hari

189,97

(B)

Muara Labuh (C)

2381,42

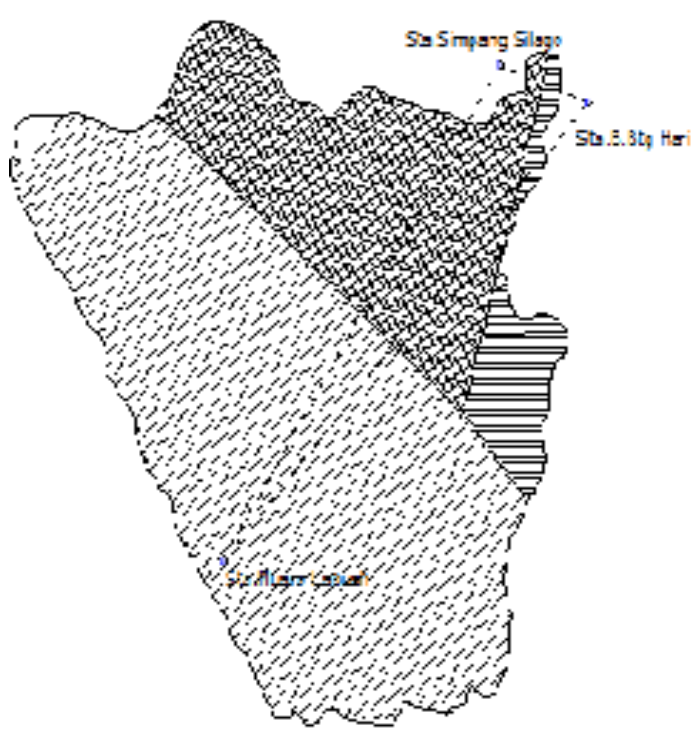

Gambar 2. Peta Metode Poligon Thiessen

Setelah diketahui luas catcment area masing-masing stasiun curah hujan selanjutnya dikalikan dengan kedalaman hujan yang ada pada stasiun tersebut dan dibagi dengan luas total ketiga stasiun curah hujan dan hasilnya dapat dilihat pada tabel 3 .

Tabel 3. Rekapitulasi Rerata Curah Hujan

\begin{tabular}{crr} 
N0 & \multicolumn{2}{c}{ CH RATA-RATA } \\
\hline & Poligon Thiessen & Aritmatika \\
\hline 1 & 160,33 & 221,70 \\
2 & 79,01 & 84,74 \\
3 & 78,76 & 80,28 \\
4 & 90,44 & 101,66 \\
5 & 73,74 & 82,38 \\
6 & 95,55 & 182,89 \\
7 & 146,69 & 151,68 \\
8 & 137,48 & 131,89 \\
9 & 95,51 & 104,59 \\
10 & 99,88 & 124,45 \\
11 & 110,97 & 108,59 \\
12 & 96,39 & 119,30 \\
13 & 145,58 & 152,42 \\
14 & 114,53 & 132,66 \\
15 & 139,59 & 168,07 \\
\hline
\end{tabular}

\section{Analisa Distribusi Hujan}

Analisa frekuensi bertujuan untuk mencari hubungan antara besarnya suatu kejadian ekstrem (maksimum atau minimum) dan frekuensinya berdasarkan probabilitas (kamiana,2011). Dalam analisa frekuensi data hujan atau data debit untuk memperoleh nilai hujan rencana atau debit rencana, dikenal beberapa distribusi kontinu yang sering digunakan yaitu Gumbel, Normal, log Normal dan Log Person Type III. Menurut buku Triatmojo (2008) untuk menentukan jenis distribusi hujan yang akan digunakan, maka harus disesuaikan dengan sifat-sifat dari distribusi tersebut, seperti yang ditunjukkan pada seperti tabel.3.

Tabel 3. Persyaratan parameter statistik untuk menentukan jenis distribusi

\begin{tabular}{|l|l|}
\hline \multicolumn{1}{|c|}{ Distribusi } & \multicolumn{1}{c|}{ Persyaratan } \\
\hline \multirow{2}{*}{ Gumbel } & $\mathrm{C}_{\mathrm{s}}=1,14$ \\
& $\mathrm{C}_{\mathrm{k}}=5,4$ \\
\hline Normal & $\mathrm{C}_{\mathrm{s}} \approx 0$ \\
\hline
\end{tabular}




\begin{tabular}{|l|l|}
\hline & $\mathrm{C}_{\mathrm{k}} \approx 3$ \\
\hline Log Normal & $\begin{array}{l}\mathrm{C}_{\mathrm{s}}=\mathrm{C}_{\mathrm{v}}{ }^{3}+3 \mathrm{C}_{\mathrm{v}}{ }^{6} \mathrm{C}_{\mathrm{k}}=\mathrm{C}_{\mathrm{v}} 8+6 \mathrm{C}_{\mathrm{v}}{ }^{6}+15 \mathrm{C}_{\mathrm{v}}{ }^{4}+ \\
16 \mathrm{C}_{\mathrm{v}}{ }^{2}+3\end{array}$ \\
\hline $\begin{array}{l}\text { Log Person Type } \\
\text { III }\end{array}$ & Selain dari nilai diatas \\
\hline
\end{tabular}

a. Koefisien kepencengan $\left(\mathrm{C}_{\mathrm{s}}\right)$

$$
\mathrm{Cs}=\frac{\mathrm{n} \sum_{\mathrm{i}=1}^{\mathrm{i}}(\mathrm{Xi}-\overline{\mathrm{X}})^{3}}{(\mathrm{n}-1)(\mathrm{n}-2)(\mathrm{S})^{3}}
$$

b. Koefisien kurtosis $\left(\mathrm{C}_{\mathrm{k}}\right)$

$$
\mathrm{Ck}=\frac{\mathrm{n}^{2} \sum_{\mathrm{i}=1}^{\mathrm{i}}(\mathrm{Xi}-\overline{\mathrm{X}})^{4}}{(\mathrm{n}-1)(\mathrm{n}-2)(\mathrm{n}-3)(\mathrm{S})^{4}}
$$

c. Koefisien Vaariasi $\left(\mathrm{C}_{\mathrm{v}}\right)$

$$
\mathrm{Cv}=\frac{\mathrm{S}}{\overline{\mathrm{X}}}
$$

d. Nilai rata-rata $(\overline{\mathrm{X}})$

$$
\overline{\mathrm{X}}=\frac{\sum_{\mathrm{i}=1}^{\mathrm{i}} \mathrm{Xi}}{\mathrm{n}}
$$

e. Standar Deviasi

$$
\mathrm{S}=\sqrt{\frac{\sum_{\mathrm{I}-1}^{\mathrm{n}}(\mathrm{Xi}-\overline{\mathrm{X}})^{2}}{\mathrm{n}-1}}
$$

Hasil pengukuran dispersi untuk metoda aritmatika dan poligon thiesen disajikan dalam tabel 4

Tabel.4. Hasil Dispersi

\begin{tabular}{lllr}
\hline No & Dispersi & Aritmatika & P. Thiessen \\
\hline 1 & $\mathrm{Cs}$ & 0,81205 & 0,4103 \\
2 & $\mathrm{Cv}$ & 0,3087 & 0,2540 \\
3 & $\mathrm{Ck}$ & 3,9283 & 2,3758 \\
\hline
\end{tabular}

Hasil perhitungan sebaran data atau uji dispersi dengan parameter statistik seri hujan rata-rata dengan metoda Aritmatika dapat dilihat pada tabel 5

Tabel 5. Cek Syarat Jenis Distribusi dengan Aritmatika

\begin{tabular}{llc}
\hline Jenis sebaran & Syarat & Hasil \\
\hline Gumbel & $\mathrm{Cs}=1,14$ & $\mathrm{Cs}=0,812$ \\
& $\mathrm{Ck}=5,4$ & $\mathrm{Ck}=3,928$ \\
Normal & $\mathrm{Cs}=0$ & $\mathrm{Cs}=0,812$
\end{tabular}

$$
\begin{array}{lr}
\mathrm{Ck}=3 & \mathrm{Ck}=3,928 \\
\mathrm{Cs}=0,955 & \mathrm{Cs}=0,812 \\
\mathrm{Ck}=4,666 & \mathrm{Ck}=3,928
\end{array}
$$$$
\text { Log Person III Cs bukan } 0
$$

Dari hasil cek syarat jenis sebaran atau distribusi hujan dengan metoda aritmatika, dapai dilihat untuk sebaran dengan metoda distribusi Gumbel, Distribusi Normal, distribusi Log Normal tidak memenuhi syarat, maka jenis jenis distribusi yang dipilih adalah Log Person Type III.

Hasil perhitungan sebaran data atau uji dispersi dengan parameter statistik seri hujan rata-rata dengan metoda Poligon Thiessen dapat dilihat pada tabel 6

Tabel 6. Cek Syarat Jenis Distribusi dengan Aritmatika

\begin{tabular}{llc}
\hline Jenis sebaran & Syarat & Hasil \\
Gumbel & $\mathrm{Cs}=1,14$ & $\mathrm{Cs}=0,4103$ \\
& $\mathrm{Ck}=5,4$ & $\mathrm{Ck}=2,3758$ \\
Normal & $\mathrm{Cs}=0$ & $\mathrm{Cs}=0,4103$ \\
& $\mathrm{Ck}=3$ & $\mathrm{Ck}=2,3758$ \\
Log Normal & $\mathrm{Cs}=0,955$ & $\mathrm{Cs}=0,4103$ \\
& $\mathrm{Ck}=4,666$ & $\mathrm{Ck}=2,3758$ \\
Log Person III & Cs bukan 0 & Oke
\end{tabular}

Dari hasil cek syarat jenis sebaran atau distribusi hujan dengan metoda Poligon Thiessen dapai dilihat sebaran dengan metoda distribusi Gumbel, Distribusi Normal, distribusi Log Normal tidak memenuhi syarat, maka jenis distribusi yang dipilih adalah Log Person Type III.

Dari kedua metoda hasil cek syarat jenis distribusi atau sebaran metoda aritmatika dan metoda Poligon Thiessen, maka metode yang paling mendekati persyaratan tersebut adalah distribusi probabilitas Log Person Type III. Setelah cek syarat jenis sebaran kedua metoda tersebut didapat, selanjutnya dilakukan pengujian distribusi probababilitas.

Pengujian Distribusi Probabilitas 
Uji Distribusi Probabilitas dimaksudkan untuk mengetahui apakah persamaan distribusi probabilitas yang dipilih dapat mewakili distribusi statistik sampel data yang dianalisis. Ada dua cara yang digunakan untuk menguji apakah jenis distribusi yang dipilih sesuai dengan data yang ada, yaitu metoda Chi-Kuadrat dan metoda

Smirnov-Kolmogorov

(Triatmojo,2013)

\section{Metoda Chi Kuadrat $\left(\chi^{2}\right)$}

Rumus yang digunakan dalam perhitungan dengan metode uji ChiKuadrat adalah sebagai berikut:

$$
\chi^{2}=\sum_{\mathrm{i}=1}^{\mathrm{n}} \frac{(\text { Of-Ef })^{2}}{\text { Ef }}
$$

Dimana:

$\chi^{2}=$ Parameter chi kuadrat terhitung

Ef = Frekuensi yang diharapkan sesuai dengan pembagian kelasnya

Of $=$ Frekuensi yang diamati pada kelas yang sama

$\mathrm{n}=$ Jumlah sub kelompok

Derajat nyata atau drajat kepercayaan $(\propto$ ) tertentu yang sering diambil adalah 5\%. Drajat kebebasan (Dk) dihitung dengan rumus :

Dimana:

$$
\mathrm{Dk}=\mathrm{k}-(\mathrm{p}+1)
$$

$\mathrm{Dk}=$ Drajat kebebasan

$\mathrm{P}$ = Banyaknya paremeter, untuk

Chi kuadrat adalah 2

$\mathrm{K}$ = Jumlah kelas distribusi

$\mathrm{n} \quad=$ Banyaknya data

Selanjutnya distribusi probabilitas yang dipakai untuk menentukan curah hujan rencana adalah distribusi probabilitas yang mempunyai simpangan maksimum terkecil dan lebih kecil dari simpangan kritis $\left(\chi^{2}<\chi^{2}\right.$ kritis $)$

A. Analisa data hujan dengan menggunakan Metoda Aritmatika diperoleh nilai Chi-Kuadrat untuk masingmasing probabilitas disajikan dalam tabel 7.
Tabel 7a. Perhitungan $\chi^{2}$ untuk Distribusi Normal untuk metoda Aritmatika

\begin{tabular}{ccccc}
\hline Interval & Ef & Of & (Of-Ef) & $\begin{array}{c}(\text { Of- } \\
\text { Ef })^{\wedge} 2 / \mathrm{Ef}\end{array}$ \\
\hline$>163,48$ & 3 & 3 & 0 & 0,000 \\
$139,84-163,48$ & 3 & 2 & -1 & 0,333 \\
$119,80-139,84$ & 3 & 3 & 0 & 0,000 \\
$96,16-119,80$ & 3 & 4 & 1 & 0,333 \\
$<96,16$ & 3 & 3 & 0 & 0 \\
\hline & 15 & 15 & & 0,67 \\
\hline
\end{tabular}

Tabel 7b. Perhitungan $\chi^{2}$ untuk Distribusi Log Normal untuk metoda Aritmatika

\begin{tabular}{ccccc}
\hline Interval & Ef & Of & $($ Of-Ef $)$ & $\begin{array}{c}(\text { Of- } \\
\text { Ef) } 2 / E f\end{array}$ \\
\hline$>160,09$ & 3 & 3 & 0 & 0,000 \\
$134,11-160,09$ & 3 & 2 & -1 & 0,333 \\
$115,42-134,11$ & 3 & 4 & 1 & 0,333 \\
$96,69-115,42$ & 3 & 3 & 0 & 0 \\
$<96,69$ & 3 & 3 & 0 & 0 \\
\hline & 15 & 15 & & 0,67 \\
\hline
\end{tabular}

Tabel 7c. Perhitungan $\chi^{2}$ untuk Distribusi Gumbel untuk metoda Aritmatika

\begin{tabular}{ccccc}
\hline Interval & Ef & Of & (Of-Ef) & $\begin{array}{c}(\text { Of- } \\
\text { Ef)^ } 2 / \mathrm{Ef}\end{array}$ \\
\hline$>168,56$ & 3 & 2 & -1 & 0,333 \\
$134,56-168,56$ & 3 & 3 & 0 & 0,000 \\
$113,25-134,56$ & 3 & 4 & 1 & 0,333 \\
$91,02-113,25$ & 3 & 3 & 0 & 0 \\
$<91,02$ & 3 & 3 & 0 & 0 \\
\hline & 15 & 15 & & 0,67 \\
\hline
\end{tabular}

Tabel 7d. Perhitungan $\chi^{2}$ untuk Distribusi Log Person Type III untuk metoda Aritmatika

\begin{tabular}{ccccc}
\hline Interval & Ef & Of & (Of-Ef) & $\begin{array}{c}(\text { Of- } \\
\text { Ef) }\end{array} \wedge^{\wedge} / \mathrm{Ef}$ \\
\hline$>160,18$ & 3 & 3 & 0 & 0,000 \\
$129,76-160,18$ & 3 & 2 & -1 & 0,333 \\
$111,04-129,76$ & 3 & 3 & 0 & 0,000 \\
$96,63-111,04$ & 3 & 4 & 1 & 0,333 \\
$<96,63$ & 3 & 3 & 0 & 0 \\
\hline & 15 & $\mathbf{1 5}$ & & 0,67 \\
\hline
\end{tabular}

Dari perhitungan di atas, diperoleh $\chi^{2}$ untuk metoda aritmatika untuk keempat distribusi 
adalah $\chi^{2}=0,67$, sedangkan batas kritis nilai Chi-Kuadrat untuk $\mathrm{dk}=2$ dengan $\alpha=5 \%$, dari tabel diperoleh nilai $\chi^{2}$ kritis $=5,991$. Dengan batas kritis 5,991, maka pemilihan distribusi dengan metoda aritmatika untuk keempat distribusi adalah memenuhi syarat

B. Analisa data hujan dengan menggunakan Metoda Poligon Thiessen diperoleh nilai Chi-Kuadrat untuk masingmasing probabilitas disajikan dalam tabel 8 .

Tabel 8a. Perhitungan $\chi^{2}$ untuk Distribusi Normal untuk metoda Poligon Thiessen

\begin{tabular}{ccccc}
\hline Interval & Ef & Of & $($ Of-Ef $)$ & $\begin{array}{c}(\text { Of- } \\
\text { Ef })^{\wedge} 2 / \mathrm{Ef}\end{array}$ \\
\hline$>134,64$ & 3 & 5 & 2 & 1,333 \\
$118,01-134,64$ & 3 & 0 & -3 & 3,00 \\
$103,92-118,01$ & 3 & 2 & -1 & 0,333 \\
$87,29-103,92$ & 3 & 5 & 2 & 1,333 \\
$<87,29$ & 3 & 3 & 0 & 0 \\
\hline & 15 & 15 & & 6,00 \\
\hline
\end{tabular}

Tabel 8b. Perhitungan $\chi^{2}$ untuk Distribusi Log Normal untuk Poligon Thiessen

Interval Ef Of (Of-Ef)

\begin{tabular}{ccccc}
\hline$>129,86$ & 3 & 5 & 2 & 1,333 \\
$113,87-129,86$ & 3 & 1 & -2 & 1,333 \\
$115,42-113,87$ & 3 & 1 & -2 & 1,333 \\
$89,33-115,42$ & 3 & 5 & 2 & 1,333 \\
$<89,33$ & 3 & 3 & 0 & 0 \\
\hline & 15 & 15 & & 5,33 \\
\hline
\end{tabular}

Tabel 8c. Perhitungan $\chi^{2}$ untuk Distribusi Gumbel untuk metoda Poligon Thiessen

\begin{tabular}{cccccc}
\multicolumn{6}{c}{ Gumbel untuk metoda Poligon Thiessen } \\
\hline Interval & Ef & Of & (Of-Ef) & $\begin{array}{c}\text { (Of- } \\
\text { Ef)^2/Ef }\end{array}$ \\
\hline$>138,22$ & 3 & 4 & 1 & 0,333 & A \\
$114,30-138,22$ & 3 & 1 & -2 & 1,333 & Ko \\
$99,31-114,30$ & 3 & 2 & -1 & 0,333 & u \\
$83,67-99,31$ & 3 & 5 & 2 & 1,333 & d \\
$<83,67$ & 3 & 3 & 0 & 0 & \\
\hline & 15 & 15 & & 3,33 & \\
\hline
\end{tabular}

Tabel 8d. Perhitungan $\chi^{2}$ untuk Distribusi Log Person Type III untuk metoda Poligon Thiessen

\begin{tabular}{ccccc}
\hline Interval & Ef & Of & (Of-Ef) & $\begin{array}{c}(\text { Of- } \\
\text { Ef })^{\wedge} 2 / \mathrm{Ef}\end{array}$ \\
\hline$>129,892$ & 3 & 3 & 0 & 1,333 \\
$111,12-129,892$ & 3 & 2 & -1 & 1,333 \\
$98,99-111,12$ & 3 & 3 & 0 & 1,333 \\
$96,63-98,99$ & 3 & 4 & 1 & 1,333 \\
$<89,29$ & 3 & 3 & 0 & 0 \\
\hline & 15 & 15 & & 5,33 \\
\hline
\end{tabular}

Dari perhitungan pemilihan distribusi untuk metoda Poligon Thiessen semuanya memenuhi syarat kecuali metoda Normal, yang mana $\chi^{2}(6)>$ dari nilai $\chi^{2}$ kritis $(5,991)$

2. Metode Smirnov - Kolmogorof

Proses perhitungan dengan metode SmirnovKolmogorof yang pertama adalah mengurutkan data dari besar kekecil atau sebaliknya. Selanjutnya tentukan peluang empiris masing-masing data yang sudah diurut tersebut $\mathrm{P}\left(\mathrm{X}_{\mathrm{i}}\right)$ berdasarkan persamaan distribusi probabilitas yang dipilih (gumbel, normal dan sebagainya). Hitung selisih $\left(\Delta \mathrm{P}_{\mathrm{i}}\right)$ antara peluang empiris dan teoritis untuk setiap data yang sudah diurut. Syarat nilai $\Delta \mathrm{P}_{\mathrm{i}}<\Delta \mathrm{P}_{\text {kritis, }}$ jika tidak artinya distribusi probabilitas yang dipilih tidak dapat diterima. Dan syarat yang harus diperhatikan juga untuk diterima jika memakai beberapa distribusi probabilitas adalah jarak penyimpangan terbesar $\Delta \mathrm{p}$ dengan kemungkinan dapat nilai lebih kecil dari dari nilai $\Delta \mathrm{P}_{\text {kritis }}$.

Dengan diketahui banyak data $(n)=15$, taraf nyata $(\propto)=5 \%$, nilai $\Delta \mathrm{P}_{\text {kritis }}$ dapat Kolmogorof yaitu 0,34 .

A. Analisa uji distribusi SmirnovKolmogorof dengan metoda Aritmatika untuk masing-masing probabilitas disajikan dalam tabel 9 .

Tabel.9. Rekap Nilai $\Delta \mathrm{P}$ dan $\Delta \mathrm{P}_{\text {kritis }}$ dengan Aritmatika

\begin{tabular}{llll}
\hline Distribusi & $\Delta \mathrm{P}$ & $\Delta \mathrm{P}_{\text {kritis }}$ & Keterangan \\
\hline
\end{tabular}




\begin{tabular}{llll}
\hline Probabilitas & & & \\
\hline Normal & 0,197 & 0,34 & memenuhi \\
Log Normal & 0,187 & 0,34 & memenuhi \\
Gumbel & 0,152 & 0,34 & memenuhi \\
Log Person & 0,186 & 0,34 & memenuhi \\
TypeIII & & & \\
\hline
\end{tabular}

Dari hasil uji kecocokan Smirnov Kolmogorof dengan perhitungan empat distribusi probabilitas, dapat disimpulkan semua distribusi memenuhi syarat, namun yang dipilih adalah $\Delta \mathrm{P}$ yang terkecil yaitu Distribusi Probabilitas Gumbel untuk menganalisis seri data hujan selanjutnya.

B. Analisa uji distribusi SmirnovKolmogorof dengan metoda Poligon Thiessen untuk masing-masing probabilitas disajikan dalam tabel 10 .

Tabel.10. Rekap Nilai $\Delta \mathrm{P}$ dan $\Delta \mathrm{P}_{\text {kritis }}$ Poligon Thiessen

\begin{tabular}{lccc}
\hline $\begin{array}{l}\text { Distribusi } \\
\text { Probabilitas }\end{array}$ & $\Delta \mathrm{P}$ & $\Delta \mathrm{P}_{\text {kritis }}$ & Keterangan \\
\hline Normal & 0,152 & 0,34 & memenuhi \\
Log Normal & 0,133 & 0,34 & memenuhi \\
Gumbel & 0,092 & 0,34 & memenuhi \\
Log Person & 0,121 & 0,34 & memenuhi \\
TypeIII & & & \\
\hline
\end{tabular}

C. Dari hasil uji kecocokan Smirnov Kolmogorof dengan perhitungan empat distribusi probabilitas, dapat disimpulkan semua distribusi memenuhi syarat, namun yang dipilih adalah $\Delta \mathrm{P}$ yang terkecil yaitu Distribusi Probabilitas Gumbel

Berikut ini hasil perhitungan uji derajat distribusi masing-masing metode perhitungan hujan rancangan dengan berbagai periode ulang ('Tahun')

Tabel 11.Rekapitulasi Hasil Uji Tingkat Kepercayaan Distribusi Metoda aritmatika

\begin{tabular}{|c|c|c|c|c|c|}
\hline \multirow[b]{3}{*}{ No } & \multirow{3}{*}{$\begin{array}{c}\text { Period } \\
\text { e } \\
\text { Ulang } \\
\text { (T) }\end{array}$} & \multicolumn{4}{|c|}{ Curah Hujan Rencana } \\
\hline & & \multicolumn{4}{|c|}{ Metode Distribusi Porbabilitas } \\
\hline & & $\begin{array}{c}\text { Norma } \\
1\end{array}$ & $\begin{array}{c}\log \\
\text { Norma } \\
1\end{array}$ & $\begin{array}{c}\text { Gumbe } \\
1\end{array}$ & $\begin{array}{c}\text { Log } \\
\text { Person } \\
\text { Type } \\
\text { III }\end{array}$ \\
\hline
\end{tabular}

\begin{tabular}{|c|c|c|c|c|c|}
\hline 1 & 2 & 107,47 & 124,41 & 124,08 & $\begin{array}{c}122,9 \\
0\end{array}$ \\
\hline 2 & 5 & 129,72 & 160,69 & 168,56 & $\begin{array}{c}167,0 \\
3 \\
\end{array}$ \\
\hline 3 & 10 & 141,37 & 182,69 & 198,01 & $\begin{array}{c}193,1 \\
8\end{array}$ \\
\hline 4 & 25 & 149,05 & 199,30 & 235,22 & $\begin{array}{c}263,7 \\
9 \\
\end{array}$ \\
\hline 5 & 50 & 161,82 & 230,32 & 262,83 & $\begin{array}{c}279,3 \\
9 \\
\end{array}$ \\
\hline 6 & 100 & 169,18 & 250,37 & 290,23 & $\begin{array}{c}295,2 \\
2 \\
\end{array}$ \\
\hline \multicolumn{6}{|c|}{ Uji Chi-Kuadrat } \\
\hline $\begin{array}{l}\text { Chi } \\
\text { Kua } \\
\text { Hitu }\end{array}$ & $\begin{array}{l}\text { at } \\
\text { at } \\
g\left(\chi^{2}\right)\end{array}$ & 0,67 & 0,67 & 0,67 & 0,67 \\
\hline $\begin{array}{l}\text { Chi } \\
\text { Kua } \\
\text { Krit }\end{array}$ & $\begin{array}{l}\text { at } \\
\left(\chi^{2} \mathrm{cr}\right)\end{array}$ & 5,991 & 5,991 & 5,991 & 5,991 \\
\hline & otesa & Oke & Oke & Oke & Oke \\
\hline \multicolumn{6}{|c|}{ Uji Smirvov - Kolmogorov } \\
\hline \multicolumn{2}{|c|}{$\begin{array}{l}\text { Smirnov- } \\
\text { Hitung }(\Delta \mathrm{p} \\
\text { mak) }\end{array}$} & 0,197 & 0,187 & 0,152 & 0,186 \\
\hline \multicolumn{2}{|c|}{$\begin{array}{lr}\text { Smirnov } & - \\
\text { Kritis } & (\Delta \mathrm{p} \\
\text { kritis }) & \end{array}$} & 0,34 & 0,34 & 0,34 & 0,34 \\
\hline \multicolumn{2}{|c|}{ Hipotesa } & Oke & Oke & Oke & Oke \\
\hline
\end{tabular}

Tabel 12.Rekapitulasi Hasil Uji Tingkat Kepercayaan Distribusi Poligon Thiessen

\begin{tabular}{|c|c|c|c|c|c|}
\hline \multirow{3}{*}{ No } & \multirow{3}{*}{$\begin{array}{l}\text { Period } \\
\text { e } \\
\text { Ulang } \\
\text { (T) }\end{array}$} & \multicolumn{4}{|c|}{ Curah Hujan Rencana } \\
\hline & & & & & Log \\
\hline & & $\begin{array}{c}\text { Norma } \\
1\end{array}$ & $\begin{array}{c}\text { Log } \\
\text { Norma } \\
1\end{array}$ & $\begin{array}{c}\text { Gumbe } \\
1\end{array}$ & $\begin{array}{l}\text { Person } \\
\text { Type } \\
\text { III }\end{array}$ \\
\hline 1 & 2 & 107,47 & 107,71 & 106,93 & $\begin{array}{c}102,9 \\
0\end{array}$ \\
\hline 2 & 5 & 129,72 & 129,86 & 138,22 & $\begin{array}{c}127,0 \\
3\end{array}$ \\
\hline 3 & 10 & 141,37 & 143,23 & 158,94 & $\begin{array}{c}143,1 \\
8\end{array}$ \\
\hline 4 & 25 & 149,05 & 152,79 & 185,11 & $\begin{array}{c}163,7 \\
9\end{array}$ \\
\hline 5 & 50 & 161,82 & 170,10 & 204,53 & $\begin{array}{c}179,3 \\
9\end{array}$ \\
\hline 6 & 100 & 169,18 & 180,96 & 223,81 & $\begin{array}{c}195,2 \\
2\end{array}$ \\
\hline \multicolumn{6}{|c|}{ Uji Chi-Kuadrat } \\
\hline $\begin{array}{l}\text { Chi } \\
\text { Kua } \\
\text { Hitı }\end{array}$ & $\begin{array}{ll} & - \\
\text { at } \\
g\left(\chi^{2}\right)\end{array}$ & 6 & 5,333 & 5,333 & 3,333 \\
\hline $\begin{array}{l}\text { Chi } \\
\text { Kua } \\
\text { Krit }\end{array}$ & $\begin{array}{l}\text { at } \\
\left(\chi^{2} \mathrm{cr}\right)\end{array}$ & 5,991 & 5,991 & 5,991 & 5,991 \\
\hline & otesa & Oke & Oke & Oke & Oke \\
\hline
\end{tabular}




\begin{tabular}{|l|c|c|c|c|}
\hline \multicolumn{5}{|c|}{ Uji Smirnov - Kolmogorov } \\
\hline $\begin{array}{l}\text { Smirnov- } \\
\text { Hitung } \\
\text { mak) }\end{array}(\Delta \mathrm{p}$ & 0,152 & 0,133 & 0,092 & 0,121 \\
\hline $\begin{array}{l}\text { Smirnov } \\
\text { Kritis } \\
\text { kritis }\end{array}$ & $0,-34$ & 0,34 & 0,34 & 0,34 \\
\hline \multicolumn{1}{|c|}{ Hipotesa } & Oke & Oke & Oke & Oke \\
\hline
\end{tabular}

\section{SIMPULAN}

Berdasarkan dari hasil analisis, maka diperoleh kesimpulan sebagai berikut :

1. Dari ketiga data stasiun curah hujan yang berada disekitar Bendung Batang Hari,setelah dilakukan uji konsistensi kurva massa ganda, data tersebut dapat dilakukan untuk analisis selanjutnya dengan Metoda Aritmatika dan Metoda Poligon thiessen dan pola distribusi yang cocok adalah distribusi Gumbel.

2. Hasil perhitungan $\chi^{2}$ dengan menggunakan keempat distribusi untuk metoda Aritmatika dengan uji Chi Kuadrat semuanya memenuhi syarat $\chi^{2}=0,67<$ $\chi^{2}$ cr dan dengan Smirnov-Kolmogorof yang memenuhi syarat adalah dengan simpangan terkecil yaitu Gumbel.

3. Hasil perhitungan $\chi^{2}$ dengan menggunakan keempat distribusi untuk metoda Poligon Thiessen dengan uji Chi Kuadrat semuanya memenuhi syarat kecuali Normal

4. Hasil perhitungan $\chi^{2}$ dengan menggunakan keempat distribusi untuk metoda Poligon Thiessen dengan uji Smirnov Kolmogorof semuanya memenuhi syarat dan yang yang dipilih adalah $\Delta \mathrm{P}$ yang terkecil yaitu Distribusi Probabilitas Gumbel. Untuk selanjutnya metode inilah yang dipakai untuk analisis banjir rancangan.

\section{SARAN}

Sebaiknya dalam pemilihan lokasi stasiun hujan yang akan dipakai untuk banjir rancangan harus yang berdekatan dengan pengaliran sungai dan juga diperhatikan aksebilitasnya guna kemudahan dalam pengontrolan tinggi hujan

\section{DAFTAR PUSTAKA}

Girsang,F.2008. Analisis Curah Hujan Untuk Pendugaan debit Puncak dengn metode Rasional pada DAS Belawan Kabupaten Deli Serdang, Skripsi Universitas Sumatera Utara

Kamiana,M,I.2011. Teknik Perhitungan Debit Banjir Rancangan Bangunan Air, Yogyakarta : Graha Ilmu

Lashari,dkk.2017. Jurnal teknik Sipil dan Perencanaan Volume 19. Universitas Negeri Semarang

Seyhan,E.1990. Dasar-dasar Hidrologi. Yogyakarta : Gajah Mada University Press

Triatmojo,B.2013. Hidrologi Terapan. Yogyakarta : Beta Offset . 